\title{
HUBUNGAN KEPATUHAN ANTI RETROVIRAL THERAPY(ART) SATU BULAN TERAKHIR DENGAN KUALITAS HIDUP PASIEN HIV/AIDS DI RSUD DR. SOETOMO SURABAYA
}

\author{
Syahru Ramadhaan Unzila1, Siti Rahayu Nadhiroh', Erwin Astha Triyono ${ }^{2}$ \\ ${ }^{1}$ Departemen Gizi Kesehatan, Fakultas Kesehatan Masyarakat, Universitas Airlangga, Surabaya, Indonesia \\ ${ }^{2}$ Unit Perawatan Intermediet Penyakit Infeksi, Rumah Sakit Umum Daerah Doktor Soetomo, Surabaya, Indonesia) \\ Email: syahru-r-u-11@fkm.unair.ac.id
}

\begin{abstract}
ABSTRAK
Kepatuhan Anti Retroviral Therapy (ART) memengaruhi kualitas hidup pasien HIV/AIDS dan sebaliknya kualitas hidup memengaruhi kepatuhan ART secara positif, dimana ODHA dengan kualitas hidup lebih baik mungkin mempunyai kemampuan lebih besar untuk patuh pada regimen ARTnya. Tujuan penelitian ini adalah untuk menganalisis hubungan kepatuhan ART dengan kualitas hidup pasien HIV/AIDS Rawat Jalan dalam empat bidang di RSUD Dr. Soetomo Surabaya. Jenis penelitian ini adalah observasional dengan rancang bangun cross sectional. Besar sampel adalah 94 pasien HIV/AIDS rawat jalan dan dipilih menggunakan teknik accidental sampling. Data dianalisis menggunakan uji korelasi Spearman. Hasil penelitian menunjukkan bahwa sebagian besar pasien HIV/AIDS berumur 36-55 tahun $(53,2 \%)$, berjenis kelamin laki-laki $(59,6 \%)$, berstatus gizi normal $(42,6 \%)$, memiliki kepatuhan ART satu bulan terakhir tinggi (79,8\%), dan memiliki skor rata-rata kualitas hidup dalam semua bidang berkisar antara 50-60 (3040\%). Penelitian ini menunjukkan bahwa ada hubungan antara kepatuhan ART satu bulan terakhir dengan kualitas hidup dalam bidang kesehatan fisik $(r=0,212, \mathrm{P}=0,040)$ dan lingkungan $(\mathrm{r}=0,258, \mathrm{P}=0,012)$. Disarankan program pelayanan AIDS yang komprehensif terutama dengan memperhatikan faktor kesehatan fisik dan lingkungan dijalankan untuk meningkatkan kualitas hidup pasien HIV/AIDS. Dibutuhkan penelitian longitudinal dengan jumlah responden yang lebih banyak dan penggunaan kombinasi instrumen pengukuran untuk memahami faktor-faktor yang berhubungan dengan kepatuhan ART dan kualitas hidup.
\end{abstract}

Kata kunci: jenis kelamin, kepatuhan ART, kualitas hidup, status gizi, umur

\begin{abstract}
Anti Retroviral Therapy (ART) adherence influenced HIVIAIDS patient's quality of life and otherwise quality of life influenced ART adherence positively, where the better quality of life of People Living With HIVIAIDS (PLWHA), the more ability of patient to adhere on their ART regiment. The purpose of this study was to analyze association between ART adherence and outpatient HIVIAIDS patient's quality of life in four domains at RSUD Dr. Soetomo Surabaya. This study was an observational study with cross sectional design. Sample was 94 HIVAIDS patients 's outpatient and selected by using accidental sampling technique. The data was analyzed using Spearman correlation test. The result of study showed that most of HIVAIDS patients were 36-55 years old (53.2\%), male (59.6\%), normal nutritional status (42.6\%), having high ART adherence in the last one month (79.8\%), and having quality of life's mean score in all domains ranged at 50-60 (30-40\%). This study showed that there was an association between ART adherence in the last one month and quality of life in physical health $(r=0.212, P=0.040)$ and environment's domain $(r=0.258$, $P=0.012)$. It is suggested a comprehensive AIDS care program primarily with considering physical health and environment factors that could increase HIV/AIDS patient's quality of life. It is suggested a longitudinal study with greater numbers of respondent and combine the use of measurement instrument to understand factors related to ART adherence and quality of life.
\end{abstract}

Keywords: sex, ART adherence, quality of life, nutritional status, age

\section{PENDAHULUAN}

Pada tahun 2009, Indonesia diestimasikan akan memiliki penduduk dengan HIV positif berjumlah 186.000 orang. Hasil estimasi ini mulai terbukti dengan adanya peningkatan jumlah Orang dengan HIV/AIDS (ODHA) pada kelompok orang berperilaku risiko tinggi tertular HIV yaitu penjaja seks komersial dan penyalahguna Narkotika, Psikotropika, dan Zat Aditif (NAPZA) suntikan di beberapa provinsi. Jawa Timur adalah salah satu 
provinsi yang mengalami peningkatan jumlah kasus tersebut sehingga Jawa Timur tergolong sebagai daerah dengan tingkat epidemi terkonsentrasi (concentrated level of epidemic) (Kemenkes RI, 2011). Kasus HIV/AIDS di Indonesia juga sudah menyebar ke semua provinsi, dengan jumlah kasus HIV dan AIDS terbanyak salah satunya berada di Jawa Timur yang menduduki peringkat ke-2 dari 33 provinsi di Indonesia dengan kasus HIV berjumlah 19.249 kasus, sedangkan kasus AIDS di Jawa Timur berjumlah 8976 kasus (Kemenkes RI, 2014).

Triyono dan Misutarno (2013) mengungkapkan Rumah Sakit Umum Daerah (RSUD) Dr. Soetomo sebagai rumah sakit rujukan ODHA berdasarkan Keputusan Menteri RI Nomor 782/MENKES/ SK/IV/2011 tentang Rumah Sakit Rujukan bagi Orang Dengan HIV dan AIDS (ODHA) memiliki tugas penting dalam penanganan HIV di Jawa Timur dan Indonesia bagian Timur. Kasus HIV/ AIDS di RSUD Dr. Soetomo sampai tahun 2012 tercatat pada data kunjungan pasien rawat jalan baru HIV/AIDS mencapai 805 pasien (menurun $2,9 \%$ dari tahun 2011), sedangkan data kunjungan pasien rawat jalan poli Unit Perawatan Intermediet Penyakit Infeksi (UPIPI) tahun 2012 mencapai 14.433 pasien (meningkat $27,5 \%$ dari tahun 2011) dan yang rawat inap mencapai 679 pasien (menurun 12,5\% dari tahun 2011).

UPIPI RSUD Dr. Soetomo Surabaya menemukan 50 penderita HIV/AIDS per bulan, baik baru atau lama yang baru terdata. Pasien rawat jalan yang rutin berkunjung di UPIPI berjumlah sekitar 1.780 pasien, sedangkan jumlah pasien rawat jalan yang berkunjung setiap bulannya mencapai 2.000 orang yang terdiri dari 1.950 pasien dewasa $(97,5 \%)$ dan 50 pasien anak-anak (2,5\%). Pasien ini akan mendapatkan ART guna menurunkan beban epidemi pada masyarakat melalui keteraturan meminum obat/kepatuhan ART tinggi (Setiawan \& Arishandi, 2015).

Terapi yang tersedia bagi pasien HIV/AIDS adalah ART, terapi ini tidak dapat menyembuhkan HIV/AIDS, tetapi dapat memaksimalkan supresi replikasi HIV. ART bertujuan untuk meningkatkan kualitas hidup ODHA dengan cara menekan replikasi virus dan meningkatkan jumlah CD4 pada tubuh penderita. ART diharapkan dapat membuat muatan virus (viral load) pada plasma pasien menjadi lebih rendah dari batas kuantifikasi/tidak terdeteksi. Selain penurunan viral load, ART diharapkan dapat meningkatkan jumlah CD4 guna mencegah terjadinya infeksi oportunistik pada pasien (Fletcher \& Kakuda, 2005). Alasan kegagalan ART yang paling sering ditemui adalah rendahnya kepatuhan Anti Retroviral Therapy (ART) (Coffey \& Volberding, 2012).

Kepatuhan merupakan salah satu indikator keberhasilan ART. Kepatuhan dan kesinambungan berobat lebih menitikberatkan pada peran dan kesadaran pasien (bukan hanya mengikuti perintah dokter), dengan dibantu dokter atau petugas kesehatan, pendamping dan ketersediaan obat (Kemenkes RI, 2011).

Berdasarkan hasil penelitian yang dilakukan Maisarah (2012) pada 17 pasien HIV/AIDS yang menjalani perawatan di RSUP H. Adam Malik Medan didapatkan temuan bahwa sebagian besar pasien HIV/AIDS memiliki kualitas hidup yang buruk, di mana 5 pasien $(29,41 \%)$ berkualitas hidup baik dan 12 pasien $(70,58 \%)$ berkualitas hidup buruk. Sari, et al. (2013) menemukan hanya $68,3 \%$ pasien HIV/AIDS yang memiliki tingkat kepatuhan ART tinggi pada bulan Januari-Juni 2011 di poli UPIPI RSUD Dr. Soetomo.

Tabel 1 menunjukkan total pasien ART semakin meningkat dari tahun 2012 hingga Mei 2014, namun peningkatan jumlah pasien tersebut tidak diikuti dengan peningkatan persentase total kepatuhan terhadap total pasien ART yang justru mengalami penurunan dari tahun 2012 hingga Mei 2014.

Kepatuhan ART adalah faktor positif dalam kualitas hidup seorang pasien HIV/ AIDS, khususnya dalam bidang kesehatan fisik

Tabel 1. Data Kepatuhan Pasien HIV/AIDS UPIPI RSUD Dr. Soetomo Tahun 2012-Mei 2014

\begin{tabular}{lccc}
\hline \multicolumn{1}{c}{ Uraian } & $\mathbf{2 0 1 2}$ & $\mathbf{2 0 1 3}$ & Mei 2014 \\
\hline Total Pasien ART & 1097 & 1268 & 1418 \\
Total Kepatuhan & 972 & 1047 & 1140 \\
$\begin{array}{l}\text { Persentase Total } \\
\text { Kepatuhan terhadap }\end{array}$ & $88,61 \%$ & $82,57 \%$ & $80,40 \%$ \\
Total Pasien ART & & & \\
\hline
\end{tabular}

Sumber: Monev UPIPI, tahun 2014 
karena kepatuhan ART memperbaiki imunitas, mengendalikan viral load dan menunda progresi penyakit (Silva, et al., 2014). Kepatuhan ART tinggi berhubungan dengan kualitas hidup pasien dalam bidang kesehatan fisik karena kontribusinya pada peningkatan jumlah CD4 secara pesat (Wang, et al., 2009). Kepatuhan ART rendah berhubungan dengan kualitas hidup pasien dalam bidang kesehatan fisik karena asupan obat antiretroviral yang bertambah. (Sarna, et al., 2008)

Kepatuhan ART berhubungan dengan kualitas hidup pasien HIV/AIDS dalam bidang psikologis di mana kepatuhan ART rendah berhubungan dengan adanya efek samping yang tidak diinginkan dan depresi parah (Sarna, et al., 2008). Efek samping yang tidak diinginkan pasien dalam jangka pendek adalah mual dan muntah, sedangkan dalam jangka panjang adalah lipodistropi dan dislipidemia (Silva, et al., 2014).

Kepatuhan ART berhubungan dengan kualitas hidup pasien HIV/AIDS dalam bidang hubungan sosial di mana kepatuhan ART tinggi berhubungan secara signifikan dengan dukungan keluarga (Nischal, et al., 2005), hubungan keluarga yang baik dan adanya kepercayaan pada pemberi pelayanan (Ajithkumar, et al., 2011).

Kepatuhan ART berhubungan dengan kualitas hidup pasien HIV/AIDS dalam bidang lingkungan di mana kepatuhan ART tinggi berhubungan dengan berkurangnya biaya rumah sakit (Wang, et al., 2009) dan kepatuhan ART rendah berhubungan dengan tingkat edukasi yang rendah dan pengangguran (Sarna, et al., 2008).

Belum adanya data kualitas hidup pasien HIV/ AIDS di UPIPI beserta masalah yang diuraikan di atas, maka perlu dilakukan penelitian mengenai hubungan kepatuhan ART satu bulan terakhir dengan kualitas hidup pasien HIV/AIDS Rawat Jalan dalam bidang kesehatan fisik, psikologis, hubungan sosial, dan lingkungan di UPIPI RSUD Dr. Soetomo Surabaya. Tujuan penelitian ini adalah untuk menganalisis hubungan kepatuhan ART satu bulan terakhir dengan kualitas hidup pasien HIV/ AIDS Rawat Jalan dalam bidang kesehatan fisik, psikologis, hubungan sosial, dan lingkungan di UPIPI RSUD Dr. Soetomo Surabaya.

\section{METODE}

Penelitian ini merupakan penelitian observasional dengan rancang bangun cross sectional. Populasi dalam penelitian ini adalah semua pasien HIV/AIDS rawat jalan yang berkunjung ke poli UPIPI RSUD Dr. Soetomo pada saat penelitian berlangsung.

Sampel yang diteliti adalah pasien HIV/ AIDS di poli UPIPI RSUD Dr. Soetomo Surabaya dengan kriteria inklusi yaitu pasien yang sudah ditegakkan diagnosa HIV/AIDS, pasien HIV/AIDS Rawat Jalan yang berkunjung di poli UPIPI pada saat penelitian berlangsung, responden berumur $\geq 18$ tahun dan sedang tidak hamil bagi responden perempuan. Besar sampel penelitian ini adalah 94 responden yang ditentukan dengan teknik non probability sampling dan diambil dengan teknik accidental sampling.

Teknik pengumpulan data yang digunakan dalam penelitian ini ada 2 yaitu pertama, data primer meliputi pengisian kuesioner dan pengukuran Indeks Massa Tubuh meliputi berat badan dan tinggi badan. Kedua, data sekunder meliputi data agregat kepatuhan ART pasien HIV/ AIDS poli UPIPI terbaru, data kunjungan yang diperkirakan dan data kunjungan yang sebenarnya pada rekam medis guna mengidentifikasi tingkat kepatuhan ART pasien satu bulan terakhir. Instrumen yang digunakan dalam penelitian ini adalah kuesioner karakteristik pasien (umur, jenis kelamin, dan status gizi) dan kualitas hidup dalam bidang kesehatan fisik, psikologis, hubungan sosial dan lingkungan (WHOQOL-BREF, 2004), timbangan digital, tip atau pita dari baja yang elastik dengan panjang 2 meter (Microtoise), dan alat tulis.

Analisis skor kualitas hidup dilakukan dengan cara menjumlah skor responden pada tiap bidang (raw score) kemudian mengkonversi raw score tiap bidang menjadi transformed score (skala 0-100) menggunakan tabel konversi tiap bidang. Interpretasi dari transformed score yaitu skor yang lebih tinggi pada tiap bidang menunjukkan kualitas hidup yang lebih tinggi dalam bidang tersebut. Kedua, analisis bivariat yang bertujuan untuk 
mengetahui ada tidaknya hubungan dan kekuatan antara variabel kepatuhan ART satu bulan terakhir dengan kualitas hidup pasien HIV/AIDS.

Penelitian ini telah mendapatkan Keterangan Kelaikan Etik dari Komite Etik Penelitian Kesehatan RSUD Dr. Soetomo Surabaya dengan nomor 575/Panke.KKE/XI/2015.

\section{HASIL DAN PEMBAHASAN}

\section{Gambaran Karakteristik Pasien HIV/AIDS}

Karakteristik pasien terdiri dari umur, jenis kelamin dan status gizi. Distribusi pasien HIV/ AIDS menurut karakteristik pasien dapat dilihat pada Tabel 2.

Tabel 2 menunjukkan bahwa sebagian besar responden berada pada kategori umur 36-55 tahun (dewasa menengah) dengan persentase sebesar $53,2 \%$. Hasil penelitian ini tidak sesuai dengan hasil penelitian Wulandari (2012) yang menemukan fakta bahwa sebagian besar pasien HIVAIDS RSUD Dr. Soetomo berada pada kategori usia produktif yang berusia antara 26-35 tahun (56,9\%). Hal ini menunjukkan bahwa kemungkinan terjadi kesamaan responden di mana pasien HIV/AIDS yang menjadi responden pada penelitian Wulandari pada bulan Januari tahun

Tabel 2. Distribusi Responden Menurut Karakteristik Pasien di UPIPI RSUD Dr. Soetomo Surabaya Tahun 2015

\begin{tabular}{|c|c|c|}
\hline Variabel & $\begin{array}{c}\text { Total } \\
(\mathrm{N}=94)\end{array}$ & $\begin{array}{c}\text { Persentase } \\
(\%)\end{array}$ \\
\hline \multicolumn{3}{|l|}{ Umur } \\
\hline $\begin{array}{l}\text { 18-35 tahun } \\
\text { (Dewasa Muda) }\end{array}$ & 44 & 46,8 \\
\hline $\begin{array}{l}36-55 \text { tahun } \\
\text { (Dewasa Menengah) }\end{array}$ & 50 & 53,2 \\
\hline $\begin{array}{l}\text { 55-75 tahun } \\
\text { (Dewasa Tua) }\end{array}$ & 0 & 0,0 \\
\hline \multicolumn{3}{|l|}{ Jenis Kelamin } \\
\hline Laki-laki & 56 & 59,6 \\
\hline Perempuan & 38 & 40,4 \\
\hline \multicolumn{3}{|l|}{ Status Gizi } \\
\hline Underweight $(<18,5)$ & 18 & 19,1 \\
\hline $\begin{array}{l}\text { Normal } \\
(18,5-<23,0)\end{array}$ & 40 & 42,6 \\
\hline Overweight $(23,0-<27,5)$ & 29 & 30,9 \\
\hline $\begin{array}{l}\text { Obese } \\
(\geq 27,5)\end{array}$ & 7 & 7,4 \\
\hline
\end{tabular}

2012 juga menjadi responden pada penelitian ini yang dilakukan pada bulan Desember Tahun 2015 sehingga mengakibatkan terjadinya pergeseran umur pasien HIV/AIDS yang pada awalnya berada pada kategori umur 26-35 tahun menjadi 36-55 tahun.

Sebagian besar responden berjenis kelamin laki-laki dengan persentase sebesar $59,6 \%$. Hal ini sesuai dengan jumlah infeksi HIV yang dilaporkan menurut jenis kelamin pada laporan perkembangan HIV-AIDS Triwulan III Tahun 2014 yang menunjukkan jumlah penderita HIV/AIDS lakilaki lebih banyak dibanding perempuan dengan persentase $58,1 \%$ dibanding $41,9 \%$ (Kemenkes RI, 2014) dan hasil penelitian Wulandari (2012) yang menemukan pasien HIV/AIDS sebagian besar berjenis kelamin laki-laki $(56,9 \%)$. Hal ini menunjukkan bahwa trend jumlah penderita HIV/ AIDS menurut jenis kelamin tetap didominasi oleh laki-laki yang cenderung meningkat dari tahun ke tahun. Trend pria sebagai jumlah penderita HIV/AIDS terbanyak ini disebabkan oleh jumlah Laki-laki Seks dengan Laki-laki (LSL) yang terhitung sebagai penderita baru dan lama semakin bertambah. Hal ini sesuai dengan laporan supplemental surveilans HIV Centers for Disease Control and Prevention (CDC, 2012) yang menemukan fakta bahwa pada tahun 2010 jumlah ODHA terbanyak adalah laki-laki (76\%), dan 69\% dari total ODHA laki-laki adalah gay, bisexual, dan LSL. Gay, bisexual dan LSL juga merupakan salah satu faktor risiko HIV/AIDS di Indonesia di mana pada tahun 2014 jumlah kasus AIDSnya mencapai 1366 kasus (Kemenkes RI, 2014).

Mayoritas responden memiliki status gizi normal $\left(18,5-<23,0 \mathrm{~kg} / \mathrm{m}^{2}\right)$ dengan persentase sebesar $42,6 \%$. Hasil penelitian ini cukup sesuai dengan hasil penelitian Nadhiroh (2012) yang menemukan fakta bahwa sebagian besar pasien HIV/AIDS RSUD Dr. Soetomo memiliki status gizi normal $\left(18,5-25,0 \mathrm{~kg} / \mathrm{m}^{2}\right)$. Hal ini menunjukkan bahwa kondisi fisik pasien HIV/AIDS rawat jalan sebagian besar memang masih seperti orang sehat. Secara kasat mata, perbedaan orang sehat dengan pasien HIV/AIDS rawat jalan terletak pada lukaluka fisik pada kulit yang mulai bermunculan. 
Tabel 3. Distribusi Responden Menurut Kepatuhan ART Satu Bulan Terakhir di UPIPI RSUD Dr. Soetomo Surabaya Tahun 2015

\begin{tabular}{lcc}
\hline \multicolumn{1}{c}{ Variabel } & $\begin{array}{c}\text { Total } \\
(\mathbf{N}=\mathbf{9 4})\end{array}$ & $\begin{array}{c}\text { Persentase } \\
\mathbf{( \% )}\end{array}$ \\
\hline Kepatuhan ART Satu Bulan Terakhir: & \\
Tinggi (>95\%) & 75 & 79,8 \\
Sedang $(85-95 \%)$ & 12 & 12,8 \\
Rendah $(<85 \%)$ & 7 & 7,4 \\
\hline
\end{tabular}

\section{Gambaran Kepatuhan ART Satu Bulan Terakhir Pasien HIV/AIDS}

Kepatuhan ART satu bulan terakhir dapat dilihat dari perilaku responden dalam mengambil obat ARV setiap bulan sesuai dengan tanggal yang diperkirakan, kemudian dikategorikan menjadi 3 kategori yaitu ( $>95 \%$ )/ tinggi jika $<3$ hari setelah tanggal yang diperkirakan, (85-95\%) / sedang jika 3-7 hari setelah tanggal yang diperkirakan dan $(<85 \%) /$ rendah jika $>7$ hari setelah tanggal yang diperkirakan. Distribusi pasien HIV/AIDS menurut kepatuhan ART satu bulan terakhir dapat dilihat pada Tabel 3.

Tabel 3 menunjukkan bahwa sebagian besar pasien HIV/AIDS memiliki kepatuhan ART satu bulan terakhir tinggi (>95\%) dengan persentase sebesar $79,8 \%$.

\section{Gambaran Kualitas Hidup Pasien HIV/AIDS}

Kualitas hidup terdiri dari 4 bidang, yaitu kesehatan fisik, psikologis, hubungan sosial dan lingkungan dapat dilihat dari nilai/ skor yang menunjukkan tingkat kualitas hidup responden dalam bidang kesehatan fisik, psikologis, hubungan sosial dan lingkungan dengan rentang $0-100$ yang terbagi menjadi 4 kuartil berdasarkan data yang diperoleh. Distribusi pasien HIV/AIDS menurut kualitas hidup dapat dilihat pada Tabel 4:

Tabel 4 menunjukkan bahwa sebagian besar pasien HIV/AIDS memiliki skor kualitas hidup dalam bidang kesehatan fisik sebesar 45-56 dengan persentase sebesar $42,6 \%$, bidang psikologis sebesar 57-69 dengan persentase sebesar 33,0\%, bidang hubungan sosial sebesar 1-50 dengan persentase sebesar $42,6 \%$, bidang lingkungan sebesar 1-50 dengan persentase sebesar 31,9\%. Skor rata-rata kualitas hidup pasien dalam bidang
Tabel 4. Distribusi Responden Menurut Kualitas Hidup di UPIPI RSUD Dr. Soetomo Surabaya Tahun 2015

\begin{tabular}{|c|c|c|}
\hline Variabel & $\begin{array}{c}\text { Total } \\
(\mathrm{N}=94)\end{array}$ & Persentase (\%) \\
\hline $\begin{array}{l}\text { Kesehatan Fisik } \\
\text { (rerata) }\end{array}$ & \multicolumn{2}{|c|}{$54,80 \pm 11,85$} \\
\hline $1-44$ & 30 & 31,9 \\
\hline $45-56$ & 40 & 42,6 \\
\hline $57-63$ & 9 & 9,6 \\
\hline 64-100 & 15 & 16,0 \\
\hline $\begin{array}{l}\text { Psikologis } \\
\text { (rerata) }\end{array}$ & \multicolumn{2}{|c|}{$55,88 \pm 14,01$} \\
\hline $1-44$ & 27 & 28,7 \\
\hline $45-56$ & 30 & 31,9 \\
\hline $57-69$ & 31 & 33,0 \\
\hline $70-100$ & 6 & 6,4 \\
\hline $\begin{array}{l}\text { Hubungan Sosial } \\
\text { (rerata) }\end{array}$ & \multicolumn{2}{|c|}{$59,45 \pm 15,37$} \\
\hline $1-50$ & 40 & 42,6 \\
\hline $51-56$ & 16 & 17,0 \\
\hline $57-69$ & 18 & 19,1 \\
\hline $70-100$ & 20 & 21,3 \\
\hline $\begin{array}{l}\text { Lingkungan } \\
\text { (rerata) }\end{array}$ & \multicolumn{2}{|c|}{$60,10 \pm 12,77$} \\
\hline $1-50$ & 30 & 31,9 \\
\hline $51-56$ & 24 & 25,5 \\
\hline $57-69$ & 23 & 24,5 \\
\hline $70-100$ & 17 & 18,1 \\
\hline
\end{tabular}

kesehatan fisik sebesar 54,80, psikologis sebesar 55,88 , hubungan sosial sebesar 59,45, dan lingkungan sebesar 60,10.

Hubungan Kepatuhan ART Satu Bulan Terakhir dengan Kualitas Hidup Pasien HIV/ AIDS dalam Bidang Kesehatan Fisik, Psikologis, Hubungan Sosial, dan Lingkungan

Berikut ini disajikan hasil tabulasi silang dan uji hubungan antara kepatuhan ART dengan kualitas hidup dalam empat bidang, yaitu kesehatan fisik, psikologis, hubungan sosial, dan lingkungan:

Pasien yang memiliki kepatuhan ART tinggi sebagian besar memiliki skor 45-56 (45,3\%) dalam bidang kesehatan fisik, memiliki skor 45-56 (33,3\%) dan 57-69 (33,3\%) dalam bidang psikologis, memiliki skor 1-50 (46,7\%) dalam bidang hubungan sosial, dan memiliki skor $1-50$ $(36,0 \%)$ dalam bidang lingkungan.

Hasil uji korelasi Spearman di atas menunjukkan 2 temuan yaitu pertama, nilai 
Tabel 5. Hubungan antara Kepatuhan ART Satu Bulan Terakhir dengan Kualitas Hidup di UPIPI RSUD Dr. Soetomo Surabaya Tahun 2015

\begin{tabular}{|c|c|c|c|c|c|c|c|c|}
\hline \multirow{3}{*}{ Kualitas Hidup } & \multicolumn{6}{|c|}{ Kepatuhan ART Satu Bulan Terakhir } & \multirow{3}{*}{$\rho$} & \multirow{3}{*}{$\mathbf{r}$} \\
\hline & \multicolumn{2}{|c|}{ Tinggi } & \multicolumn{2}{|c|}{ Sedang } & \multicolumn{2}{|c|}{ Rendah } & & \\
\hline & $\mathbf{n}$ & $\%$ & $\mathbf{n}$ & $\%$ & $\mathbf{n}$ & $\%$ & & \\
\hline \multicolumn{9}{|l|}{ Kesehatan Fisik } \\
\hline $1-44$ & 26 & $34,7 \%$ & 3 & $25,0 \%$ & 1 & $14,3 \%$ & & \\
\hline $45-56$ & 34 & $45,3 \%$ & 2 & $16,7 \%$ & 4 & $57,1 \%$ & $0,040^{*}$ & 0,212 \\
\hline $57-63$ & 6 & $8,0 \%$ & 3 & $25,0 \%$ & 0 & $0,0 \%$ & & \\
\hline $64-100$ & 9 & $12,0 \%$ & 4 & $33,3 \%$ & 2 & $28,6 \%$ & & \\
\hline Total $(\mathrm{N}=94)$ & 75 & $100,0 \%$ & 12 & $100,0 \%$ & 7 & $100,0 \%$ & & \\
\hline \multicolumn{9}{|l|}{ Psikologis } \\
\hline $1-44$ & 21 & $28,0 \%$ & 3 & $25,0 \%$ & 3 & $42,9 \%$ & & \\
\hline $45-56$ & 25 & $33,3 \%$ & 3 & $25,0 \%$ & 2 & $28,6 \%$ & 0,957 & 0,006 \\
\hline $57-69$ & 25 & $33,3 \%$ & 5 & $41,7 \%$ & 1 & $14,3 \%$ & & \\
\hline $70-100$ & 4 & $5,3 \%$ & 1 & $8,3 \%$ & 1 & $14,3 \%$ & & \\
\hline Total $(\mathrm{N}=94)$ & 75 & $100,0 \%$ & 12 & $100,0 \%$ & 7 & $100,0 \%$ & & \\
\hline \multicolumn{9}{|l|}{ Hubungan Sosial } \\
\hline $1-50$ & 35 & $46,7 \%$ & 3 & $25,0 \%$ & 2 & $28,6 \%$ & & \\
\hline $51-56$ & 13 & $17,3 \%$ & 2 & $16,7 \%$ & 1 & $14,3 \%$ & 0,123 & 0,160 \\
\hline $57-69$ & 12 & $16,0 \%$ & 3 & $25,0 \%$ & 3 & $42,9 \%$ & & \\
\hline $70-100$ & 15 & $20,0 \%$ & 4 & $33,3 \%$ & 1 & $14,3 \%$ & & \\
\hline Total $(\mathrm{N}=94)$ & 75 & $100,0 \%$ & 12 & $100,0 \%$ & 7 & $100,0 \%$ & & \\
\hline \multicolumn{9}{|l|}{ Lingkungan } \\
\hline $1-50$ & 27 & $36,0 \%$ & 3 & $25,0 \%$ & 0 & $0,0 \%$ & & \\
\hline $51-56$ & 20 & $26,7 \%$ & 2 & $16,7 \%$ & 2 & $28,6 \%$ & $0,012^{*}$ & 0,258 \\
\hline $57-69$ & 18 & $24,0 \%$ & 3 & $25,0 \%$ & 2 & $28,6 \%$ & & \\
\hline $70-100$ & 10 & $13,3 \%$ & 4 & $33,3 \%$ & 3 & $42,9 \%$ & & \\
\hline Total $(\mathrm{N}=94)$ & 75 & $100,0 \%$ & 12 & $100,0 \%$ & 7 & $100,0 \%$ & & \\
\hline
\end{tabular}

$\mathrm{P}>0,5$ antara kepatuhan ART 1 bulan terakhir dengan kualitas hidup dalam bidang psikologis dan hubungan sosial yang berarti menunjukkan tidak adanya hubungan antara kepatuhan ART 1 bulan terakhir dengan kualitas hidup dalam bidang psikologis dan hubungan sosial. Kedua, nilai $\mathrm{P}<$ 0,5 antara kepatuhan ART 1 bulan terakhir dengan kualitas hidup dalam bidang kesehatan fisik dan lingkungan yang berarti menunjukkan adanya hubungan antara kepatuhan ART 1 bulan terakhir dengan kualitas hidup dalam bidang kesehatan fisik dan lingkungan.

Nilai $r$ yang berkisar antara $0,10-0,25$ dan bernilai positif $(+)$ antara kepatuhan ART 1 bulan terakhir dengan kualitas hidup dalam bidang kesehatan fisik menunjukkan kuat hubungan antara kepatuhan ART 1 bulan terakhir dengan kualitas hidup dalam bidang kesehatan fisik lemah dan arah hubungan searah.

Nilai $r$ yang berkisar antara $0,25-0,75$ dan bernilai positif $(+)$ antara kepatuhan ART 1 bulan terakhir dengan kualitas hidup dalam bidang lingkungan menunjukkan kuat hubungan antara kepatuhan ART 1 bulan terakhir dengan kualitas hidup dalam bidang lingkungan sedang dan arah hubungan searah.

Tidak adanya hubungan antara kepatuhan ART satu bulan terakhir dengan kualitas hidup dalam bidang psikologis dan hubungan sosial serta adanya hubungan antara kepatuhan ART satu bulan terakhir dengan kualitas hidup dalam bidang kesehatan fisik dan lingkungan dapat disebabkan oleh 2 hal menurut Wang, et al. (2009) yaitu pertama, mayoritas pasien HIV/AIDS yang menjadi sampel dalam penelitian baru menjalani ART dalam jangka pendek ( $\leq 6$ bulan). Kedua, infeksi HIV telah mempengaruhi semua aspek kualitas hidup secara mendalam. Walaupun ART dapat meningkatkan kondisi fisik dan mengurangi biaya rumah sakit pasien HIV, psikologis, dan hubungan sosial, yang mana berhubungan erat dengan status sosial pasien dan diskriminasi sosial terhadap AIDS, jarang dapat ditingkatkan oleh kepatuhan ART saja. 
Hasil penelitian ini sesuai dengan hasil penelitian Silva, et al. (2014) yang menemukan kepatuhan ART memiliki hubungan yang signifikan dengan kepatuhan ART dalam bidang kesehatan fisik $(\mathrm{P}=0,005)$ dan pernyataannya yang menyatakan kepatuhan ART adalah faktor positif dalam kualitas hidup seorang pasien HIV/ AIDS, khususnya dalam bidang kesehatan fisik karena kepatuhan ART memperbaiki imunitas, mengendalikan viral load dan menunda progresi penyakit.

Hasil penelitian ini juga sesuai dengan hasil penelitian Wang, et al. (2009) yang menemukan kepatuhan ART memiliki hubungan yang signifikan dengan kepatuhan ART dalam bidang kesehatan fisik $(\rho=0,016)$ dan pernyataannya yang menyatakan kepatuhan ART tinggi juga berhubungan dengan kualitas hidup pasien dalam bidang fisik karena kontribusinya pada peningkatan jumlah CD4 secara pesat (Wang, et al., 2009).

Hasil penelitian ini juga sesuai dengan pernyataan Wang, et al. (2009) yang menyatakan kepatuhan ART berhubungan dengan kualitas hidup pasien HIV/AIDS dalam bidang lingkungan di mana kepatuhan ART tinggi berhubungan dengan berkurangnya biaya rumah sakit dan pernyataan Sarna, et al. (2008) yang menyatakan kepatuhan ART berhubungan dengan kualitas hidup pasien HIV/AIDS dalam bidang lingkungan di mana kepatuhan ART rendah berhubungan dengan tingkat edukasi yang rendah dan pengangguran.

Penelitian yang meneliti hubungan antara kepatuhan ART dengan kualitas hidup pasien HIVAIDS masih terbilang sedikit. Hal ini didukung dengan pernyataan Oguntibeju (2012) yang menyatakan hubungan antara kualitas hidup dengan kepatuhan belum diteliti dengan baik, tetapi kepatuhan ART diketahui berkontribusi pada kualitas hidup ODHA, dan sebagai gantinya kualitas hidup dipercaya mempengaruhi kepatuhan secara positif, di mana ODHA dengan kualitas hidup lebih baik mungkin mempunyai kemampuan lebih besar untuk patuh pada regimen ARTnya.

\section{KESIMPULAN DAN SARAN}

Ada hubungan antara kepatuhan ART satu bulan terakhir dengan kualitas hidup pasien HIV/ AIDS dalam bidang kesehatan fisik dan lingkungan dimana kepatuhan ART tinggi menyebabkan kualitas hidup pasien HIV/AIDS dalam bidang kesehatan fisik dan lingkungan juga tinggi.

Disarankan instrumen pengukuran kualitas hidup pasien HIV/AIDS sebaiknya tidak menggunakan WHOQOL-BREF, melainkan WHOQOL-HIV BREF. Program pelayanan AIDS yang komprehensif mencakup dukungan psikososial dibutuhkan untuk meningkatkan kualitas hidup pasien HIV/AIDS. Penelitian longitudinal dengan jumlah responden yang lebih banyak dan penggunaan kombinasi instrumen pengukuran dibutuhkan untuk memahami faktorfaktor yang berhubungan dengan kepatuhan ART dan kualitas hidup seiring dengan berjalannya waktu.

\section{DAFTAR PUSTAKA}

Ajithkumar, K., Neera, P.G., Rajani, P.P. (2011). Relationship between social factors and treatment adherence: a study from south India. Eastern Journal of Medicine, 16, 151.

CDC. (2012). Estimated HIV incidence among adults and adolescents in the United States, 2007-2010. United States: CDC.

Coffey, S. \& Volberding, P.A.. (2012). Overview of Antiretroviral Therapy. Hong Kong: Elsevier Saunders.

Fletcher, C.V. \& Kakuda, T.N. ( 2005). Human Immunodeficiency Virus Infection. New York: McGraw-Hill.

Kemenkes. R.I. (2011). Pedoman Nasional Tatalaksana Klinis Infeksi HIV dan Terapi Antiretroviral pada Orang Dewasa. Jakarta, Indonesia: Ditjen PP dan PL.

Kemenkes. R.I. (2014). Statistik Kasus HIV/AIDS di Indonesia. Jakarta, Indonesia: Ditjen PP dan PL.

Keputusan Menteri RI Nomor 782/MENKES/SK/ IV/2011 tentang Rumah Sakit Rujukan bagi 
Orang Dengan HIV dan AIDS (ODHA). Jakarta, Indonesia: Kemenkes. R.I.

Maisarah. (2012). Gambaran Kualitas Hidup Pasien HIV/AIDS yang Menjalani Perawatan di RSUP Haji Adam Malik Medan Tahun 2012. (Unpublished master's thesis). Universitas Sumatera Utara, Medan, Indonesia.

Nadhiroh, S.R. (2012). Hubungan Pola Makan, Komposisi Tubuh dan IMT dengan Jumlah Sel CD4+ pada pasien HIV dan AIDS di RSUD Dr. Soetomo. Laporan Penelitian. Surabaya, Indonesia: FKM Universitas Airlangga.

Nischal, K.C., Khopkar, U., Saple, D.G. (2005). Improving adherence to antiretroviral therapy. Indian J Dermatol Venereol Leprol, 71, 316-320.

Oguntibeju, O.O. (2012). Quality of life of people living with HIV and AIDS and antiretroviral therapy. HIV/AIDS - Research and Palliative Care, 4, 120. Diakses dari Dovepress Journals database.

RSUD. Dr. Soetomo. (2014). Monev UPIPI. Surabaya, Indonesia: UPIPI.

Sarna, A., Pujari, S., Sengar, A.K. (2008) Adherence To Antiretro Viral Therapy And It's Determinants Amongst HIV Patients in India. Indian $J$ Med Res 127, 28-36.

Sari, R.J., Srihartini, I., Triyono, E.A. (2013). The Using of ARV Pattern to Patients on HIV/AIDS in UPIPI Dr. Soetomo Hospital, Surabaya, January-June 2011. Folia Medica Indonesiana, 49(3), 182-185.

Setiawan, \& Arishandi. (2015). RSUD dr Soetomo temukan 50 penderita HIV per bulan. Diakses dari http://www.antaranews.com/berita/532635/ rsud-dr-soetomo-temukan-50-penderita-hivper-bulan

Silva, A.C.O., Reis, R.K., Nogueira, J.A., Gir, E. (2014). Quality of life, clinical characteristics and treatment adherence of people living with HIV/AIDS. Rev. Latino-Am. Enfermagem, 22(6), 998-999. doi:10.1590/0104-1169.3534.2508

Triyono, E.A. \& Misutarno. (2013). Profilaksis Pasca Pajanan Mengurangi Risiko Tertular Infeksi HIV 99,9\%. Surabaya, Indonesia: MIMBAR.

Unzila, S.R. (2016). Hubungan Status Gizi dan Kepatuhan Anti Retroviral Therapy Dengan Kualitas Hidup (Studi pada Pasien HIV/AIDS Rawat Jalan di Unit Perawatan Intermediet Penyakit Infeksi RSUD Dr. Soetomo Surabaya) (Unpublished master's thesis). Universitas Airlangga, Surabaya, Indonesia.

Wang, H., Zhou, J., He, G., Luo, Y., Li, X., Yang, A., Fennie, K. \& Williams, A.B. (2009). Consistent ART Adherence Is Associated with Improved Quality of Life, CD4 Counts, and Reduced Hospital Costs in Central China. AIDS RESEARCH AND HUMAN RETROVIRUSES, 25(8), 760-762. doi:10.1089=aid.2008.0173

WHO. (2004). The World Health Organization Quality Of Life (WHOQOL)-BREF. Geneva: WHO Press.

Wulandari Y. (2012). Hubungan Kepatuhan ARV dengan Status Gizi Pasien HIV/AIDS (Unpublished master's thesis). Universitas Airlangga, Surabaya, Indonesia. 